\title{
Compression behaviour of clay bricks prisms, wallets and walls - Coating influence
}

\author{
Comportamiento a la compresión de prismas, mini-paredes y paredes de ladrillos de arcilla - \\ Influencia del revestimiento
}

António Azevedo (Main Author)

CONSTRUCT-LFC, Departamento de Engenharia Civil, Universidade do Porto

Rua Dr. Roberto Frias, s/n; 4200-465 Porto (Portugal)

antonio.costaazevedo@fe.up.pt

João Quesado Delgado (Corresponding Author)

CONSTRUCT-LFC, Departamento de Engenharia Civil, Universidade do Porto

Rua Dr. Roberto Frias, $s / n$; 4200-465 Porto (Portugal)

jdelgado@fe.up.pt

\section{Ana Guimarães}

CONSTRUCT-LFC, Departamento de Engenharia Civil, Universidade do Porto

Rua Dr. Roberto Frias, s/n; 4200-465 Porto (Portugal)

anasofia@fe.up.pt

\section{Fernando Artur Silva}

Departamento de Engenharia Civil, Universidade Católica de Pernambuco

Rua do Principe, 526, Boa Vista - Recife (Brazil)

artur@unicap.br

\section{Romildo Oliveira}

Departamento de Engenharia Civil, Universidade Católica de Pernambuco

Rua do Principe, 526, Boa Vista - Recife (Brazil)

romilde@unicap.br

Manuscript Code: 1107

Date of Acceptance/Reception: 13.03.2019/13.04.2018

DOI: $10.7764 /$ RDLC.18.1.123

\begin{abstract}
This work describes an experimental study carried out on running bond 195 red clay prisms, of two and three ceramic blocks, with and without cement mortar coating and some samples reinforced with mesh, subjected to axial compression in order to enhance the capacity of masonry. The prisms were subjected to compressive loading and all of them had deformation control on each face with a deflectometer, to obtain information about the structural behaviour of the prisms. The experimental results indicate an increase both in the compressive load capacity of the coated prisms and in those that use coatings based on reinforced mortar, not complying with the specifications of conventional structural mortar. The load ratios of prism/wallettes and prisms with two blocks/prisms with three blocks were satisfactory.
\end{abstract}

Keywords: Clay blocks; Axial compression; Structural masonry; Reinforced mortar; Coating; Experimental tests.

\section{Resumen}

Este trabajo describe un estudio experimental llevado a cabo sobre 195 prismas de arcilla roja, de dos y tres bloques de cerámica, con y sin recubrimiento de mortero de cemento y algunas muestras reforzadas con malla, sometidos a compresión axial para mejorar la capacidad de la mampostería. Los prismas se sometieron a cargas de compresión y todos ellos tenían control de deformación en cada cara con un deflectómetro, para obtener información sobre el comportamiento estructural de los prismas. Los resultados experimentales indican un aumento tanto en la capacidad de carga de compresión de los prismas recubiertos como en aquellos que utilizan recubrimientos a base de mortero reforzado, que no cumplen con las especificaciones del mortero estructural convencional. Las relaciones de carga de prisma/mini-pared y prismas con dos bloques/prismas con tres bloques fueron satisfactorias. 


\section{Brief state of the art}

It is important in masonry design to determine the appropriate ultimate compressive strength of the masonry material. Masonry is a material built from units and mortar that induce an anisotropic behaviour for the composite (Peña, Calavera, \& Llorens, 2011; Vercher, Cubel, Gil, \& Lerma, 2018). The lack of knowledge on the properties of the composite material imposes low assessments of the strength capacity of the masonry wall (Mohamad, Lourenço, Roman, Barbosa, \& Rizzat, 2012). Atkinson, Noland, Abrams, \& McNary (1985) state that the prediction of compressive strength and deformation of full scale masonry based on compressive tests of stack-bond masonry prism and the interpretation of the results of prism tests have a significant influence on the allowable stress and stiffness used in masonry design.

There have been numerous studies performed on the behaviour of masonry prisms under axial compression (Ewing, \& Kowalsky, 2004; Kaushik, Rai, \& Jain, 2007a \& 2007b). The effects of variables such as the height-to-thickness ratio of the prism, mortar type and grout strength, unit geometry, and various capping compounds have been the point of focus of many researchers (Gumaste, Nanjunda Rao, Venkatarama Reddy, \& Jagadish, 2007; Sumathi, \& Raja Mohan, 2014). Several authors analysed the relative strengths of masonry units and mortar, the thickness of mortar joints, shape of the units, mortar bedding methods, type of testing (prism or wallet) and masonry specimen aspect ratio (Hamid, \& Chukwunenye, 1986; Thaickavil, \& Thomas, 2018; Thamboo, \& Dhanasekar, 2019).

\section{Description of the problem}

Masonry buildings using hollow clay blocks have begun in Brazil in the mid 80's in residential constructions up to 4 storey high buildings. Such type of building technique has as one of its feature the use of non-structural units to support loading beyond its self-weight and it was used in the Metropolitan Region of Recife as a solution to the Brazilian housing deficit during several years. Oliveira, Silva, Sobrinho, \& Azevedo (2017) reported many problems with such type of building, including partial and total collapses caused by the deterioration of clay and concrete units used in the foundations.

In the last two decades clay structural masonry system has increased in some states of Brazil, mainly by the availability of blocks of high compressive strength produced in modular sizes. However, tests carried out in the last twenty years in Brazil (Cavalheiro, \& Gomes, 2002) have shown that the average compressive strength of unreinforced clay walls is only $34 \%$ of the average compressive strength of the blocks, and the average compressive strength of two block prisms is $50 \%$ of the unit strength (Cavalheiro, \& Arantes, 2004).

Some structural clay block producers may provide blocks of two or three resistances, with different prices, depending on composition of clay mix, burning temperature, and even different cross sections varying coring patterns. Despite the great interest, only few studies have been carried out and published in Brazil on the influence of reinforced mortar coating on the compressive strength of clay brick masonry prisms.

Materials and Methods

\section{Ceramic bricks}

Experimental tests with red clay prisms were performed in the Laboratory of Construction Materials of Catholic University of Pernambuco, Brazil. The red clay brick blocks used had dimensions of $91 \times 191 \times 190 \mathrm{~mm}^{3}$ (with a tolerance of $\pm 3 \mathrm{~mm}$ ) and an average density of $2,620 \mathrm{~kg} / \mathrm{m}^{3}$. Overall, a total of 195 prisms were built and tested (see Table 1). The reason to investigate 2 and 3 blocks prisms was to find out which one best chose the results to masonry wallets and walls. All the applicable ASTM standards or Brazilian standards (NBR) were followed in building, curing, capping, and testing of the prisms and the components.

After hardening the capping layers, the specimens were completely submerged in a tank with water for a period not lesser than 6 hours, as established in the Brazilian standard NBR 15270-1 (2017). The machine used to carry out the tests was the Universal Testing Machine a facility of the Laboratory of Construction Materials of Catholic University of Pernambuco, Brazil. The specimens were tested in saturated conditions and placed in the press so that their centre of gravity coincides with the load axis of the press plates. The results obtained are presented in Table 1. 
Table 1. Description of the tested samples (Source: Self-elaboration, 2017).

\begin{tabular}{|c|c|c|c|}
\hline Ref. & Samples tested & Dimension $(\mathrm{cm} \times \mathrm{cm})$ & Area $\left(\mathrm{cm}^{2}\right)$ \\
\hline \multicolumn{4}{|c|}{ Prims with 2 clay blocks } \\
\hline $2 \mathrm{P}-1$ & Uncoated prims & $9 \times 19$ & 171 \\
\hline $2 \mathrm{P}-3$ & $\begin{array}{l}\text { Prisms with a coating of } 3 \mathrm{~cm} \text { of mix ratio 1:1:6 } \\
\text { (cement:lime:sand) }\end{array}$ & $15 \times 19$ & 285 \\
\hline $2 \mathrm{P}-5$ & $\begin{array}{l}\text { Prisms with a coating of } 3 \mathrm{~cm} \text { and mix ratio 1:2:9 } \\
\text { (cement:lime:sand) }\end{array}$ & $15 \times 19$ & 285 \\
\hline $2 \mathrm{P}-7$ & $\begin{array}{l}\text { Prisms with a coating of } 3 \mathrm{~cm} \text { and mix ratio } 1: 1: 6 \\
\text { (cement:lime:sand) reinforced with a POP mesh of } 10 \times 10 \mathrm{~cm} \\
\text { and } 4.2 \mathrm{~mm} \text { of diameter }\end{array}$ & $15 \times 19$ & 285 \\
\hline \multicolumn{4}{|c|}{ Prims with 3 clay blocks } \\
\hline $3 \mathrm{P}-1$ & Uncoated prisms & $9 \times 19$ & 171 \\
\hline $3 \mathrm{P}-2$ & Prisms with a mix ratio of 1:3 (cement:sand) & $10 \times 19$ & 190 \\
\hline $3 \mathrm{P}-3$ & $\begin{array}{l}\text { Prisms with a coating of } 3 \mathrm{~cm} \text { of mix ratio 1:1:6 } \\
\text { (cement:lime:sand) }\end{array}$ & $15 \times 19$ & 285 \\
\hline $3 \mathrm{P}-4$ & $\begin{array}{l}\text { Prisms with a coating of } 1.5 \mathrm{~cm} \text { and mix ratio 1:2:9 } \\
\text { (cement:lime:sand) }\end{array}$ & $12 \times 19$ & 228 \\
\hline $3 P-5$ & $\begin{array}{l}\text { Prisms with a coating of } 3 \mathrm{~cm} \text { and mix ratio 1:2:9 } \\
\text { (cement:lime:sand) }\end{array}$ & $15 \times 19$ & 285 \\
\hline $3 P-6$ & $\begin{array}{l}\text { Prisms with a coating of } 3 \mathrm{~cm} \text { of mix ratio 1:0.5:4.5 } \\
\text { (cement:lime:sand) }\end{array}$ & $15 \times 19$ & 285 \\
\hline $3 P-7$ & $\begin{array}{l}\text { Prisms with a coating of } 3 \mathrm{~cm} \text { and mix ratio } 1: 1: 6 \\
\text { (cement:lime:sand) reinforced with a POP mesh of } 10 \times 10 \mathrm{~cm} \\
\text { and } 4.2 \mathrm{~mm} \text { of diameter }\end{array}$ & $21 \times 19$ & 399 \\
\hline $3 P-8$ & $\begin{array}{l}\text { Prisms with a coating of } 1.5 \mathrm{~cm} \text { and mix ratio } 1: 2: 9 \\
\text { (cement:lime:sand) reinforced with a POP mesh of } 10 \times 10 \mathrm{~cm} \\
\text { and } 4.2 \mathrm{~mm} \text { of diameter }\end{array}$ & $18 \times 19$ & 342 \\
\hline $3 P-9$ & $\begin{array}{l}\text { Prisms with a coating of } 3 \mathrm{~cm} \text { and mix ratio } 1: 2: 9 \\
\text { (cement:lime:sand) reinforced with a POP mesh of } 10 \times 10 \mathrm{~cm} \\
\text { and } 4.2 \mathrm{~mm} \text { of diameter }\end{array}$ & $21 \times 19$ & 399 \\
\hline
\end{tabular}

\section{Mortar}

The mortars used in this work were subject to a detailed analysis process in which their properties were investigated in the fresh state as in the hardened state. Table 2 shows the different grout mixtures (mix ratio) studied as well as their applications. These mortar mixtures were selected due to the aim to represent the wide variety of mortars used in real masonry buildings in the region.

\begin{tabular}{lcc}
\multicolumn{3}{c}{ Table 2. Mix ratio and applications } \\
\hline (Source: Self-elaboration, 2017). \\
Mix No & $\begin{array}{c}\text { Mortar } \\
\text { application }\end{array}$ & $\begin{array}{c}\text { Grout mixtures } \\
\text { (mix ratio) }\end{array}$ \\
\hline M1 & Settlement & $1: 1: 6$ (cement:lime:sand) \\
M2 & Roughcast & $1: 3$ (cement:sand) \\
M3 & Coating & $1: 2: 9$ (cement:lime:sand) \\
M1-1 & Coating & $1: 1: 6$ (cement:lime:sand) \\
M4 & Coating & $1: 0.5: 4.5$ (cement:lime:sand) \\
\hline
\end{tabular}

The fresh mortars were characterized by consistency and density test. The mortar consistency was evaluated through the procedures described in the Brazilian standard NBR 7215 (2019), allowing to verify the plasticity degree with a Flow Table. The samples were subjected to successive fall from a pre-established height, so that the more plastic the mortar, the greater its final diameter.

The mortars in the hardened state were characterized by the following tests:

- $\quad$ Axial compressive strength (rupture test), NBR5738 (2015);

- $\quad$ Diametrical compressive tensile strength, NBR 7222 (2011). 
In order to measure the axial compressive strength, six cylindrical specimens were prepared for each mortar type, with diameter of $5 \mathrm{~cm}$ and a height of $10 \mathrm{~cm}$. The specimens were cured for a period of 28 days, before carrying out the strength tests.

In order to perform diametrical compressive tensile strength tests, the procedures described in the Brazilian standard NBR 7222 (2011) were used, which establishes the preparation of six specimens, in the same way in which they were prepared for the axial compression resistance tests. The specimens were positioned in order that the contact between the plates of the test machine and the specimens gives only two generators diametrically opposite to the specimen.

A ribbed welded steel mesh was used as reinforcement of mortar coating in the prisms tested. The ribbed welded steel mesh had wires with a diameter of $4.2 \mathrm{~mm}$ and a spacing of $10 \mathrm{~cm}$ in the horizontal and vertical directions, making a steel section of $1.38 \mathrm{~cm}^{2} / \mathrm{m}$ in both directions. Steel connectors were $5.0 \mathrm{~mm}$ in diameter.

\section{Prisms and wallettes}

The wallet is an element that better represents a real masonry wall because it contains all its parts, i.e.: bed and head joints and individual units lay in and bound together by mortar. Figure 1 shows the differences between the wallets (with a height of $119 \mathrm{~cm}$ ) and a prism of two ceramic blocks (with a height of $39 \mathrm{~cm}$ ) tested. The prims with 3 blocks present a height of $59 \mathrm{~cm}$

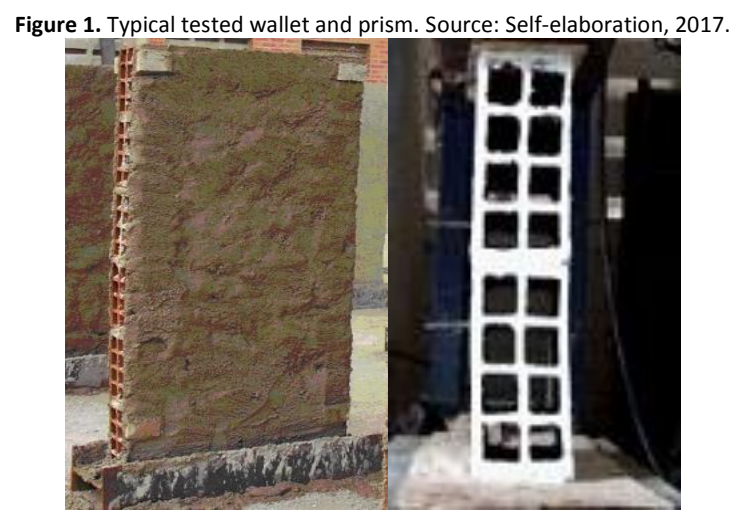

In order to perform the mechanical deflectometer readings, 400 L-shaped metallic plates, with $6 \mathrm{~cm}$ high and $2 \mathrm{~cm}$ wide, were fabricated, which were used as support base for the deflectometers. The metallic plates were fixed to the prisms, previously, in the middle third of their length, through bonding, at a distance sufficient to allow the free flow of the deflectometers.

The hydraulic jacks had $200 \mathrm{~mm}$ piston stroke and 50 ton load capacity. This allowed only one jack to be sufficient to apply the load required for rupture of the prisms. The load drive machine, controlled by software which allows a perfect handle of both displacement increment and load increase, has a servo-hydraulic working system and it is connected to the linear displacement sensors (LVDT). The displacement control of the hydraulic jacks makes it possible not only to follow the post-cracking and post-rupture, but also the shape of the rehab curve of the samples in front of the maintenance or increase of displacement.

Results and discussion

\section{Ceramic bricks}

The properties of the clay bricks used in prism construction are presented in Table 3. The mechanical characteristics of the ceramic clay brick blocks were evaluated by individual compressive strength testing. For the accomplishment of this test, a total of 13 specimens were properly prepared. The regularization of the two faces destined to the settlement perpendicular to the block length, was done with cement and a maximum thickness of $3 \mathrm{~mm}$ in order to uniformity the block surfaces. 
Table 3. Properties of the clay brick blocks used (Source: Self-elaboration, 2017).

\begin{tabular}{|c|c|c|c|}
\hline Samples & $\operatorname{IRA}^{(1)}$ & $\begin{array}{l}\text { Dry mass } \\
\text { (g) }\end{array}$ & $\begin{array}{c}\text { Compressive } \\
\text { strength }^{(2)}(\mathrm{MPa})\end{array}$ \\
\hline 1 & 6.9 & 2406 & 2.17 \\
\hline 2 & 12.6 & 2320 & 2.10 \\
\hline 3 & 9.2 & 2289 & 2.16 \\
\hline 4 & 8.6 & 2338 & 2.12 \\
\hline 5 & 17.4 & 2307 & 2.02 \\
\hline 6 & 3.9 & 2403 & 2.04 \\
\hline Average & 9.77 & 2331.4 & 2.05 \\
\hline Standard deviation & \pm 4.70 & \pm 43.86 & \pm 0.40 \\
\hline $\operatorname{cov}^{(3)}$ & --- & --- & $19 \%$ \\
\hline
\end{tabular}

\section{Mortar}

A mortar may be considered dry when the consistency index (flow table) is less than $250 \mathrm{~mm}$. Mortars with a consistency index between 260 and $300 \mathrm{~mm}$ (ex. plaster mortar) are considered plastic. Finally, mortars with a consistency index of more than $360 \mathrm{~mm}$ are considered to be fluid. The results are presented in Table 4. The axial and diametrical compressive strength results of the cylindrical specimens tested were described in Table 4.

\begin{tabular}{lccc}
\multicolumn{4}{c}{$\begin{array}{c}\text { Table 4. Consistency index, axial compression strength and tensile strength by diametrical } \\
\text { compression of the mortars tested (Source: Self-elaboration, 2017). }\end{array}$} \\
\hline Mix No & $\begin{array}{c}\text { Consistency } \\
\text { index (mm) }\end{array}$ & $\begin{array}{c}\text { Axial compressive } \\
\text { strength (MPa) }\end{array}$ & $\begin{array}{c}\text { Tensile } \\
\text { strength (MPa) }\end{array}$ \\
\hline M1 & 266 & $6.5 \pm 1.1$ & $0.9 \pm 0.2$ \\
M2 & 305 & $30.4 \pm 0.6$ & $2.8 \pm 0.9$ \\
M3 & 302 & $2.8 \pm 0.4$ & $0.8 \pm 0.3$ \\
M1-1 & 306 & $6.5 \pm 1.1$ & $0.9 \pm 0.2$ \\
M4 & 296 & $5.4 \pm 0.5$ & $0.9 \pm 0.8$ \\
\hline
\end{tabular}

\section{Prisms and Wallettes}

In this research, it was promoted two distinct, but simultaneous, ways of measuring the displacements. The first one used two displacement sensors, or LVDT's (Linear Variable Differential Transformer), a particular type of variable reluctance sensor. The second way of displacement measurement, came from the need to compare the measurements obtained with LVDT's, which take into account the entire length of the prism along with the wood deformation, with measurements of section parts of the prism length. Several procedures were tested and it was decided to measure the middle third. In this way, two pre-bonded metal plates were placed on each side of the prism to serve as support for the mechanical extensometers.

Figure 2 show the usual type of rupture observed with uncoated prisms, which was abrupt. It is also possible to observe that the prims with 2 or 3 blocks presents the same type of rupture.

Figures 3 and 4 show that the ruptures of the coated prisms start at the septa and it was transferred to the coating layer. This type of rupture it was not abrupt but by shear. The coated prisms present the same type of rupture for 2 or 3 blocks.

Figure 5 shows the rupture type observed in 2 block prisms and 3 block prisms with a coating of $3.0 \mathrm{~cm}$ and a mix ratio of 1: 1: 6. It was possible to observe that the rupture in the reinforced prisms was transferred from the septa to the first layer and then to the second layer. This rupture type was less explosive, continuing to be abrupt. 


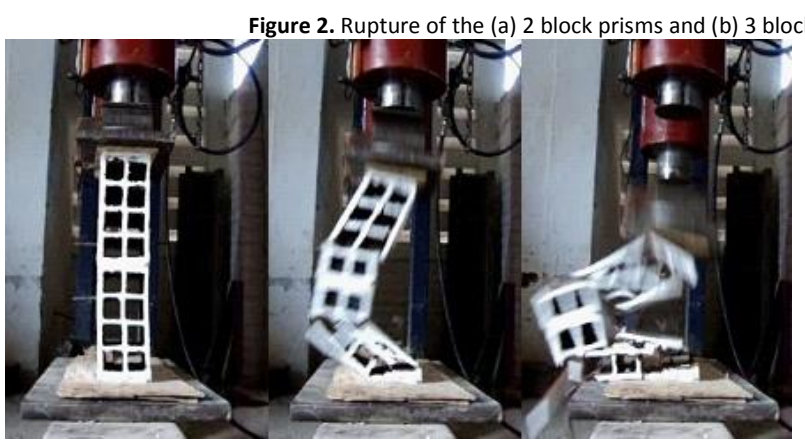

(a)

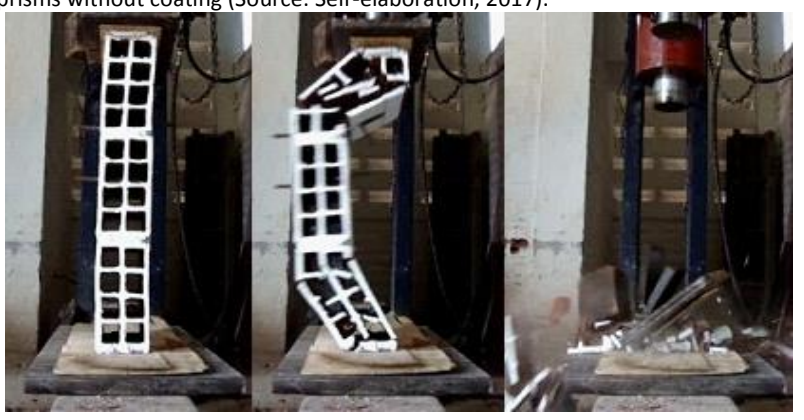

(b)

Figure 3. Rupture of the (a) 2 block prisms and (b) 3 block prisms with a coating of $3.0 \mathrm{~cm}$ and a mix ratio of 1:2:9 (Source: Self-elaboration, 2016).

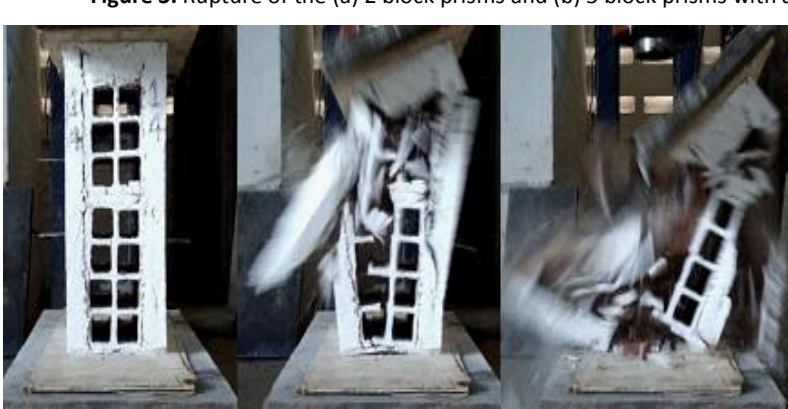

(a)

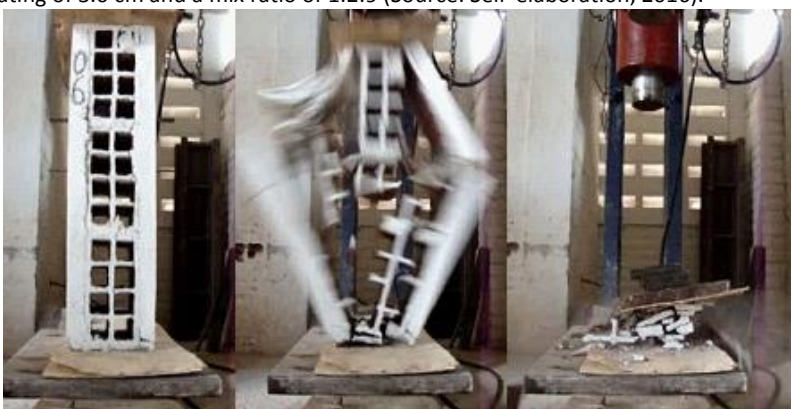

(b)

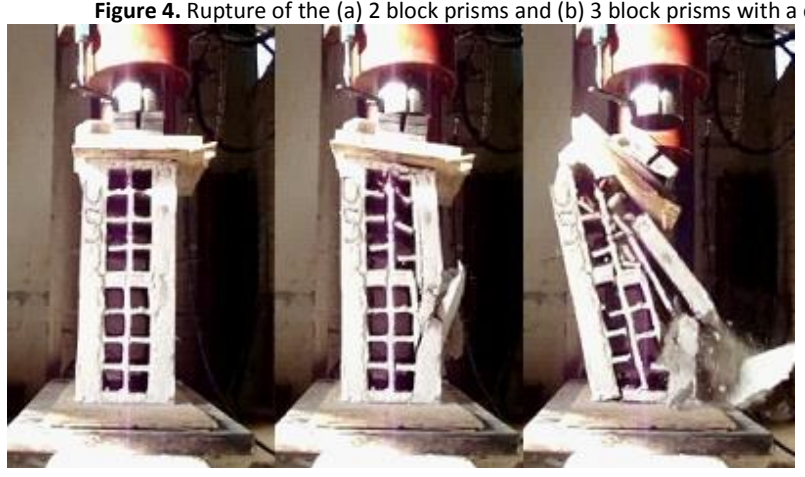

(a)

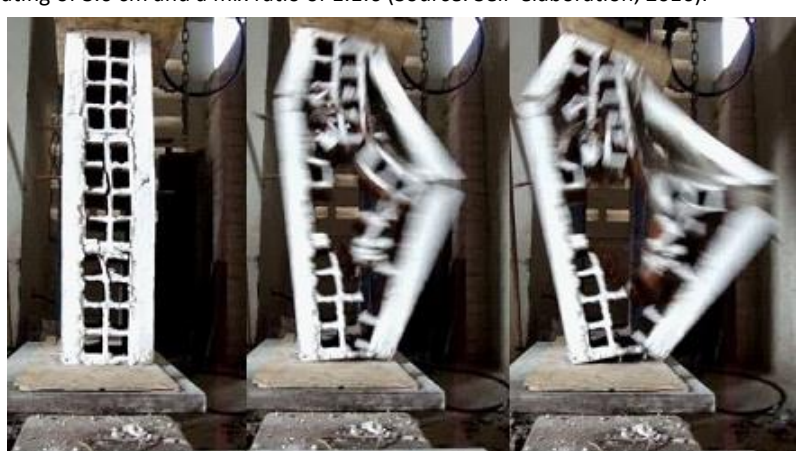

(b)

Figure 5. Rupture of the 2 block prisms with a coating of $3.0 \mathrm{~cm}$ and a mix ratio of 1:1:6 reinforced with a POP mesh of 10x10 cm and $4.2 \mathrm{~mm}$ of diameter (Source: Self-

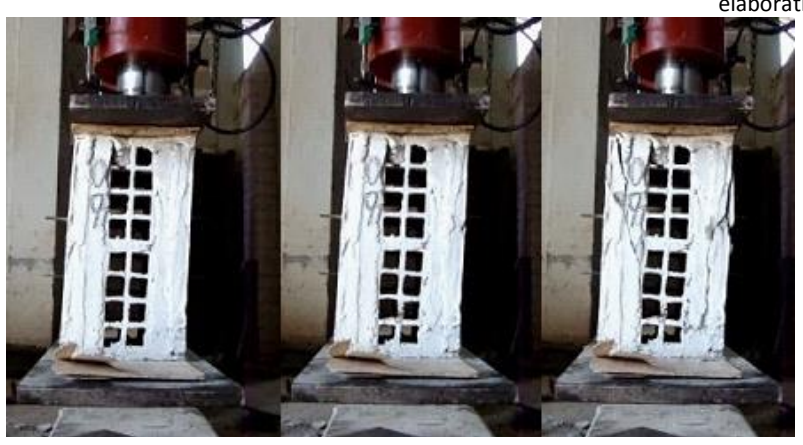

(a)

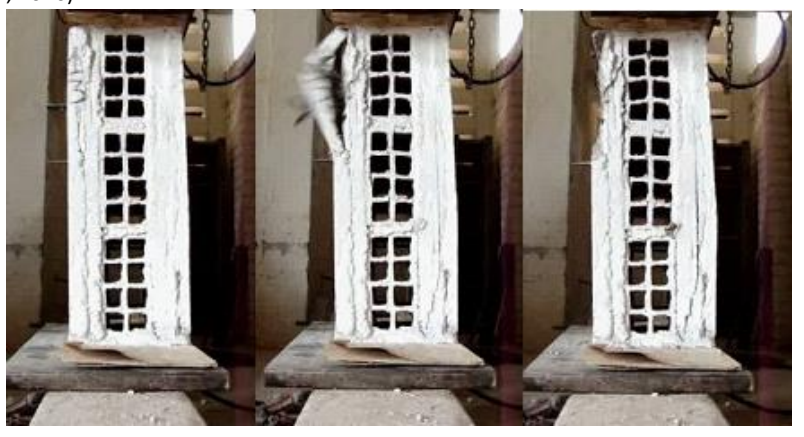

(b)

From the analyse of these figures it is possible to observe that for the prisms of 2 and 3 blocks, without coating, the hardness was lesser than in the other prisms studied. In general, it was not observed significant difference behaviour in the prisms made with strong and weak mortar, both for prisms with 2 and 3 blocks. However, the reinforced prisms present higher performance in comparison with the other prisms studied; aspects that suggest the importance of the reinforcement performed. 
Table 5 shows that the average compressive strength of the uncoated prisms with two (2P-1) or three blocks (3P-1) was not very different. In fact, for the two-block prism, the mean load was $9.72 \mathrm{kN}$ whereas for the three-block prisms this load was $9.49 \mathrm{kN}$, representing a difference of $2.4 \%$. However, it is important to note that the coefficients of variation observed were $35 \%$ and $22 \%$, for uncoated prisms with two and three blocks respectively, indicate that the observed values should be examined with caution. In addition, it should be noted that these prisms were tested on a hydraulic press machine with a load capacity of $500 \mathrm{kN}$ and the average compressive resistance values obtained were below the accuracy of the press machine, which is on the order of $10 \%$ of its capacity. In spite of these aspects it is possible to conclude that no significant difference was observed between prisms of two and three blocks.

\begin{tabular}{|c|c|c|c|c|c|c|}
\hline \multirow[b]{2}{*}{ Sample } & \multirow{2}{*}{$\begin{array}{c}\text { Thick } \\
(\mathrm{cm})\end{array}$} & \multirow{2}{*}{$\begin{array}{l}\text { Width } \\
(\mathrm{cm})\end{array}$} & \multirow{2}{*}{$\begin{array}{l}\text { Height } \\
(\mathrm{cm})\end{array}$} & \multicolumn{3}{|c|}{ Prisms - Compressive resistance $(\mathrm{kN})$} \\
\hline & & & & Average & St. Dev. & COV (\%) \\
\hline $2 \mathrm{P}-1$ & 9 & 19 & 39 & 9.72 & 3.38 & 35 \\
\hline $2 \mathrm{P}-3$ & 15 & 19 & 39 & 45.47 & 12.21 & 27 \\
\hline $2 \mathrm{P}-5$ & 15 & 19 & 39 & 50.43 & 13.61 & 27 \\
\hline $2 \mathrm{P}-7$ & 15 & 19 & 39 & 120.73 & 16.89 & 14 \\
\hline $3 P-1$ & 9 & 19 & 59 & 9.49 & 2.08 & 22 \\
\hline $3 P-2$ & 10 & 19 & 59 & 18.05 & 5.92 & 33 \\
\hline $3 P-3$ & 15 & 19 & 59 & 52.71 & 9.07 & 17 \\
\hline $3 P-4$ & 12 & 19 & 59 & 39.58 & 9.22 & 24 \\
\hline $3 P-5$ & 15 & 19 & 59 & 45.03 & 10.38 & 23 \\
\hline $3 P-6$ & 15 & 19 & 59 & 59.02 & 8.81 & 15 \\
\hline $3 P-7$ & 21 & 19 & 59 & 109.17 & 11.23 & 10 \\
\hline $3 P-8$ & 18 & 19 & 59 & 94.47 & 12.17 & 13 \\
\hline $3 P-9$ & 21 & 19 & 59 & 100.25 & 10.54 & 11 \\
\hline
\end{tabular}

Coated prisms made with low (Type O) and medium compressive-strength (Type-N) mortar, with 2 and 3 blocks, according to Table 4 , had a significant increase of load capacity, reaching up to $\sim 420 \%$ for 2 block prisms and $\sim 450 \%$ for 3 block prisms.

For the 2 block prisms with coating, it was observed that the prisms with medium compressive-strength mortar presented lower load capacity than the prisms made with low compressive-strength mortar, although the difference did not exceed $10 \%$. The coefficient of variation observed for these two situations was of the same order of magnitude, approximately $27 \%$, being this value considered statistically high, possibly explaining the unexpected result.

The observed inconsistency in the mean burst load of the 2 block prisms was not observed in the 3 block prisms. This can be justified by the fact that the coefficient of variation for the 3 block prisms was lower than for 2 block prisms.

The grout mixtures and the thickness of the mortar in the 3 block prisms had a significant influence on the compressive resistance of these elements. It is possible to observe in prisms with a single coating mortar (1:1:6), that increasing the thickness from $1.5 \mathrm{~cm}$ to $3 \mathrm{~cm}$ the load capacity increased approximately $14 \%$. While for prisms with the same thickness of $3 \mathrm{~cm}$ and different mix ratio it was observed and increase of 31\% between mix ratios of 1:1:6 and 1:0.5:4.5.

Reinforced prisms with $3 \mathrm{~cm}$ of thickness reinforced mortar and connectors showed a significant increase in the load capacity when compared to the prisms without framework and connectors. For the prisms with 2 blocks and a medium mortar with $3 \mathrm{~cm}$ of thickness the observed increase was 165\%. For the 3 block prisms with weak mortar, $1.5 \mathrm{~cm}$ or 3 $\mathrm{cm}$ thickness, this increase was $139 \%$ and $123 \%$, respectively. For the 3 block prisms medium compressive-strength mortar, $3 \mathrm{~cm}$ thickness, the increase was $107 \%$. This fact is due to the slenderness of the three blocks prisms which is higher than the two blocks one, and its strength is slower than that one. This way, the contribution of the mortar coating layer is more pronounced.

The wallets tested present a height of $119 \mathrm{~cm}, 59 \mathrm{~cm}$ of width and thickness that depends of the coating used. Tables 6 and 7 also present a comparison between the average compressive resistance of prisms with 2 and 3 blocks and ceramic wallettes. It is worth noting that the load application area of the prism is $19 \times 9 \mathrm{~cm}^{2}$ and for the wallettes is $59 \times 9 \mathrm{~cm}$, which implies a wall/prism area ratio of 3.105. All the elements tested were made under the same conditions and using the same types of materials and labour. 
The coefficients of variation of the failure load of the reinforced prisms and reinforced wallettes were very similar and relatively low, showing a greater uniformity of the final load. This fact can be explained by the presence of the steel meshes interlocked by connectors inside the mortars.

\begin{tabular}{|c|c|c|c|c|c|c|}
\hline \multirow{2}{*}{ Sample } & \multirow{2}{*}{$\begin{array}{l}\text { Thick } \\
(\mathrm{cm})\end{array}$} & \multirow{2}{*}{$\begin{array}{l}\text { Width } \\
(\mathrm{cm})\end{array}$} & \multirow{2}{*}{$\begin{array}{l}\text { Height } \\
(\mathrm{cm})\end{array}$} & \multicolumn{3}{|c|}{ Wallettes - Compressive resistance (kN) } \\
\hline & & & & Average & St. Dev. & $\operatorname{COV}(\%)$ \\
\hline W-1 & 9 & 59 & 119 & 56.3 & 8.7 & 15.4 \\
\hline W-2 & 10 & 59 & 119 & 84.9 & 16.3 & 19.2 \\
\hline W-3 & 15 & 59 & 119 & 168.3 & 33.3 & 19.8 \\
\hline W-4 & 12 & 59 & 119 & 130.4 & 24.4 & 18.7 \\
\hline W-5 & 15 & 59 & 119 & 156.5 & 16.1 & 10.3 \\
\hline W-6 & 15 & 59 & 119 & 262.2 & 42.7 & 16.3 \\
\hline W-7 & 21 & 59 & 119 & 417.1 & 63.0 & 15.1 \\
\hline W-8 & 18 & 59 & 119 & 321.0 & 47.7 & 14.9 \\
\hline W-9 & 21 & 59 & 119 & 367.0 & 49.3 & 13.4 \\
\hline
\end{tabular}

\begin{tabular}{|c|c|c|c|c|c|}
\hline Typology & $\begin{array}{c}\text { 3-blocks prisms } \\
\text { / Wallettes }\end{array}$ & $\begin{array}{l}\text { Relation of } \\
\text { areas }\end{array}$ & $\begin{array}{c}\text { 2-blocks prisms / } \\
\text { Wallettes }\end{array}$ & $\begin{array}{l}\text { Relation } \\
\text { of areas }\end{array}$ & $\begin{array}{l}\text { 3-blocks / 2- } \\
\text { blocks prisms }\end{array}$ \\
\hline Uncoated prisms & 0.17 & 0.53 & 0.17 & 0.53 & 0.98 \\
\hline Prisms with mix ratio 1:3 & 0.21 & 0.65 & $x$ & $x$ & $x$ \\
\hline $\begin{array}{l}\text { Prisms with a coating of } 1.5 \\
\mathrm{~cm} \text { and mix ratio } 1: 2: 9\end{array}$ & 0.30 & 0.93 & $x$ & $x$ & $x$ \\
\hline $\begin{array}{l}\text { Prisms with a coating of } 3 \mathrm{~cm} \\
\text { and mix ratio } 1: 2: 9\end{array}$ & 0.29 & 0.90 & 0.32 & 0.99 & 0.89 \\
\hline $\begin{array}{l}\text { Prisms with a coating of } 3 \mathrm{~cm} \\
\text { of mix ratio } 1: 1: 6\end{array}$ & 0.31 & 0.96 & 0.27 & 0.84 & 1.16 \\
\hline $\begin{array}{l}\text { Prisms with a coating of } 3 \mathrm{~cm} \\
\text { of mix ratio } 1: 0.5: 4.5\end{array}$ & 0.23 & 0.71 & $x$ & $x$ & $x$ \\
\hline $\begin{array}{l}\text { Prisms with a coating of } 1.5 \\
\mathrm{~cm} \text { and mix ratio } 1: 2: 9 \\
\text { reinforced. }\end{array}$ & 0.29 & 0.90 & $x$ & $x$ & $x$ \\
\hline $\begin{array}{l}\text { Prisms with a coating of } 3 \mathrm{~cm} \\
\text { and mix ratio } 1: 2: 9 \text { reinforced }\end{array}$ & 0.27 & 0.84 & $\mathrm{x}$ & $x$ & $x$ \\
\hline $\begin{array}{l}\text { Prisms with a coating of } 3 \mathrm{~cm} \\
\text { and mix ratio } 1: 1: 6 \text { reinforced }\end{array}$ & 0.26 & 0.81 & 0.29 & 0.90 & 0.90 \\
\hline Average & 0.26 & 0.81 & 0.26 & 0.81 & 0.98 \\
\hline Standard Deviation & 0.05 & 0.16 & 0.06 & 0.19 & 0.12 \\
\hline $\operatorname{cov}(\%)$ & 19 & 19 & 24 & 24 & 13 \\
\hline
\end{tabular}

According to the Brazilian standard NBR 15961-1 (2011), the calculation for the admissible load of a masonry wall, $P$ wall, is given by:

$P_{\text {Wall }}=f_{d} \cdot A \cdot\left\lfloor 1-\left(\frac{h}{40 . t}\right)^{3}\right\rceil$ with $\quad f_{d}=\frac{f_{k}}{\gamma_{m}}=0.7 \cdot f_{p k}$

where $f_{d}$ is the design compressive strength of masonry, $\mathrm{A}$ is the resistant cross section area, $f_{k}$ is the characteristic compressive strength of masonry, $\gamma_{m}$ is the partial safety factor for masonry, $f_{p k}$ is the characteristic compressive strength of prism, $h$ and $t$ are the wallet height and thickness, respectively.

In order to obtain a relation between the $P_{\text {Prism }}$ and $P_{\text {Wall, }}$ not taking into account the partial safety coefficient and considering the length relation of the wallettes/prism equal to $59 / 19=3.105$, the following relation was obtained: $P_{\mathrm{Pr} \text { ism }} / P_{\text {Wall }}=0.344$. 
On the other hand, a mean load ratio of the two and three block prisms was obtained experimentally when compared to the results of the wallettes being of the same order of magnitude: 0.26 . This behaviour shows that there was no significant difference in the relation between the prisms with 2 or 3 blocks and the wallettes.

The coefficients of variation associate to the failure load of the reinforced prisms and reinforced wallettes were very similar and relatively low, showing a greater uniformity of the final load. This fact can be explained by the presence of the steel meshes interlocked by connectors inside the mortars.

In literature it is possible to find several equations that relate masonry strength $\left(R_{\mathrm{M}}\right)$, mortar strength $(R m)$ and brick strength $\left(R_{1}\right)$, as the Graf equation (Fontana Cabezas, 2015):

$$
R_{M}\left(\mathrm{daN} / \mathrm{cm}^{2}\right)=\frac{R_{l}\left(4+0.10 R_{m}\right)}{16+3\left(\frac{h}{t}\right)}+K
$$

where $h$ is the height of the specimen, $t$ is the thickness of the specimen and $K$ is a constant equal to $10 \mathrm{Kg} / \mathrm{cm}^{2}$, for a well-executed wall, with $1 \mathrm{~cm}$ thick mortar joints. Graf equation was used setting the $R \mathrm{~m}$ value as the mean of the average strength obtained for mortars $65 \mathrm{daN} / \mathrm{cm}^{2}$ (6.5 MPa, see Table 3), $R_{\text {। }}$ equal to $21 \mathrm{daN} / \mathrm{cm}^{2}$ (2.05 MPa, see Table 1) and different values of the ratio $(h / t)$.

The results for uncoated prisms, using Eq. (2), show a ratio of $R_{\mathrm{M}} / R_{\mathrm{M}}$-experimental equal to approximately 0.33 (0.32 for 2-P1 and 0.34 for 3-P1), a value in accordance with the standard NBR 15961-1 (2011) and the result presented above $\left(P_{\mathrm{Pr}_{\text {ism }}} / P_{\text {Wall }}=0.344\right)$ ). For coated prisms the ratio $R_{\mathrm{M}} / R_{\mathrm{M}}$-experimental obtained was approximately 0.97 (1.03 for $3 \mathrm{P}$ $3,1.05$ for $3 \mathrm{P}-4$ and 0.88 for $3 \mathrm{P}-5)$.

Related to uncoated wallets, the ratio of $R_{\mathrm{M}} / R_{\mathrm{M}}$-experimental was equal to 0.76 (for $\mathrm{W}-1$ ), a value in accordance with the standard NBR 15961-1 (2011) and Fontana Cabezas (2015) who showed a result of 0.78. For coated wallets the ratio $R_{\mathrm{M}} / R_{\mathrm{M}}$-experimental obtained was approximately 1.20 (1.22 for W-3, 1.24 for $\mathrm{W}-4$ and 1.14 for $\mathrm{W}-5$ ).

Figures 6 and 7 show the mean displacements observed during the application of load in the prisms of two and three blocks, respectively. It is possible to observe that reinforced prisms (2P-7, 3P-7, 3P-8 and 3P-9) presented higher performance in comparison with the other prisms. One the other hand, it was not observed significant difference behaviour in the prisms made with strong/medium (mix: 1:0.5:4.5 or 1:1:6) and weak mortar (mix: 1:2:9), both for prisms with 2 blocks (2P-3 and 2P-5) and 3 blocks (3P-3 and 3P-5).

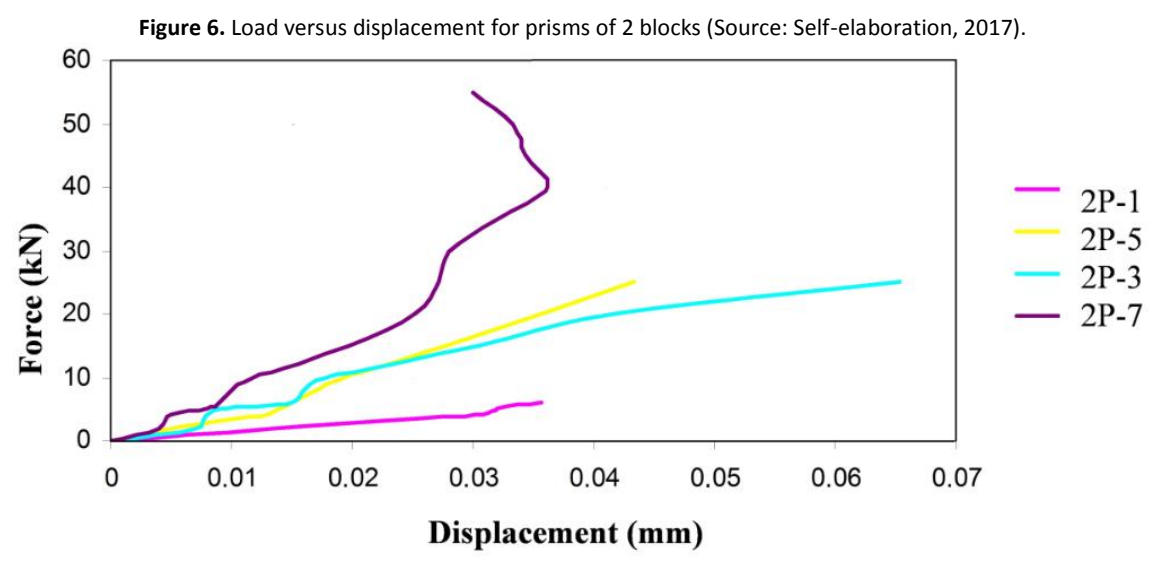


Figure 7. Load versus displacement for prisms of 3 blocks (Source: Self-elaboration, 2017).

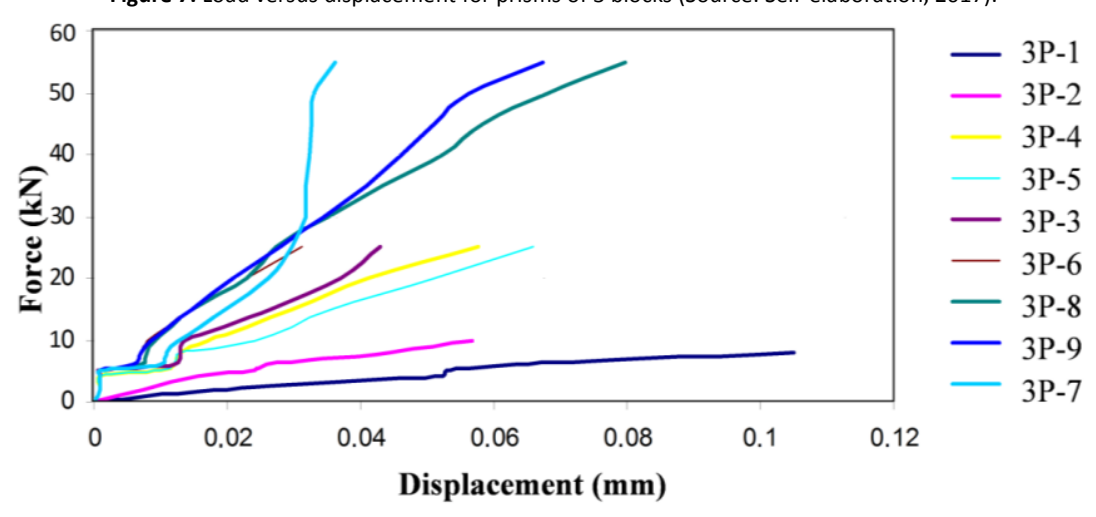

Conclusions

The tests were performed with materials from the same origin as those that were used in real masonry building: with low strength bricks carrying loads beyond their own weight. If other materials are used, the author believes that the contribution of existing mortar layers will keep on important possibly resulting in a reduction of the load capacity of the tested element. Finally, the main conclusions of this research are as follows:

- The experimental results showed that the coatings contributed to increase the vertical compressive resistance of the masonry elements studied;

- The results showed that for prisms with 3 blocks and a single coating mortar (1:1:6), an increasing of the thickness from $1.5 \mathrm{~cm}$ to $3 \mathrm{~cm}$ the load capacity increased by approximately 14\%;

- For the prisms with the same thickness, $3 \mathrm{~cm}$, and different mix ratio it was observed and increase of $31 \%$ between mix ratios of 1:1:6 and 1:0.5:4.5;

- Several types of rupture were observed in the prisms, and it is not possible to define a typical rupture form. For example, the prisms with uncoated prisms the rupture was abrupt; and the prims with 2 or 3 blocks present the same type of rupture. On the other hand, the lateral detachment ruptures of the coating layers were frequent;

- The ruptures of the coated prisms start at the septa and it was transferred to the coating layer. This type of rupture it was not abrupt but by shear. The coated prisms present the same type of rupture for 2 or 3 blocks;

- The increase observed in the load related to the reinforcement of the coated two-blocks prisms was approximately $165 \%$ and for three-blocks prisms it was of $210 \%$;

- The increment obtained with the installation of ribbed welded steel mesh inside the mortar coating was approximately $30 \%$;

- $\quad$ The relation between the maximum loads of failure of the wallettes and prisms was 0.81;

- The ratio of the maximum average loads of 2 block prisms and 3 block prisms was near 1 , showing to be equivalent two-blocks and three block prisms.

In conclusion, resistant masonry, that used non-structural blocks, cannot be thought, in any situation, as a building process to support loads beyond its self-weight. The fact that the mortar coating layer contributes to increase the load capacity of a masonry wall serves merely to explain the reasons why the respective wall did not collapse yet.

References

Aryana, S.A. (2006). Statistical analysis of compressive strength of clay brick masonry prisms. MSc. Thesis, The University of Texas, Arlington, USA.

Atkinson, R.H., Noland, J.L., Abrams, D.P., \& McNary, S. (1985). A deformation failure theory for stackbond, brick masonry prisms in compression. Proceedings of 3 rd NAMC, Arlington, p. 18-1 to 18-18.

Cavalheiro, O.P., \& Gomes, N.S. (2002). Structural masonry of hollow blocks: Test results of elements and compressive strength reducers. Proceedings of 7th International Seminar on Structural Masonry for Developing Countries, pp. 411-419, Belo Horizonte, Brazil.

Cavalheiro, O.P., \& Arantes, C.A. (2004). Influence of grout on hollow clay masonry compressive strength. Proceedings of 13th International Brick and Block Masonry Conference, Amsterdam, July 4-7. 
Ewing, B.D., \& Kowalsky, M.J. (2004). Compressive behavior of unconfined and confined clay brick masonry. Journal of Structural Engineering - ASCE, 130(4), 650-661. doi.org/10.1061/(ASCE)0733-9445(2004)130:4(650)

Fontana Cabezas, J.J. (2015). Mechanical properties of load bearing walls made of Uruguayan hollow ceramic bricks. Revista de la Construcción, 14(3), 15-21. doi.org/10.4067/S0718-915X2015000300002.

Gumaste, K.S., Nanjunda Rao, K.S., Venkatarama Reddy, B.V. \& Jagadish, K.S. (2007). Strength and elasticity of brick masonry prisms and wallettes under compression. Materials and Structures, 40(2), 241-253. doi.org/10.1617/s11527-006-9141-9

Hamid A.A., \& Chukwunenye, A.O (1986). Compression behavior of concrete masonry prisms. Journal of Structural Engineering, 112(3), 605-613. doi.org/10.1061/(ASCE)0733-9445(1986)112:3(605)

Kaushik, H.B., Rai, D.C., \& Jain, S.K. (2007a). Stress-strain characteristics of clay brick masonry under uniaxial compression. Journal of Materials in Civil Engineering - ASCE, 19(9), 728-739. doi.org/10.1061/(ASCE)0899-1561(2007)19:9(728)

Kaushik, H.B., Rai, D.C., \& Jain, S.K. (2007b). Uniaxial compressive stress-strain model for clay brick masonry. Current Science, 92(4), 497-501.

Thaickavil, N.N., \& Thomas, J. (2018). Behaviour and strength assessment of masonry prisms. Case Studies in Construction Materials, 8, 23-38. doi.org/10.1016/j.cscm.2017.12.007

NBR 5738 (2015). Concrete - Procedure for molding and curing concrete test specimens. Rio de Janeiro, Brazil.

NBR 7215 (2019). Portland cement - Determination of compressive strength of cylindrical test specimens. Rio de Janeiro, Brazil.

NBR 7222 (2011). Concrete and mortar - Determination of the tension strength by diametrical compression of cylindrical test specimens. Rio de Janeiro Brazil.

NBR 15961-1 (2011). Structural Masonry - Concrete Blocks - Part 1: Design. Rio de Janeiro, Brazil.

NBR 15270-1 (2017). Ceramic components - Clay blocks and bricks for masonry. Part 1: Requirements. Rio de Janeiro, Brazil.

Mohamad, G., Lourenço, P.B., Roman, H.R., Barbosa, C.S., \& Rizzatti, E. (2012). Stress-strain behaviour of concrete block masonry prisms under compression. Proceedings of 15th International Brick and Block Masonry Conference, Florianópolis, Brazil.

Oliveira, R.A., Silva, F.A.N., Sobrinho, C.W.A., \& Azevedo, A.A.C. 2007. Masonry buildings in the metropolitan region of Recife. Ambiente Construído, 17(2), 175-199. doi.org/10.1590/s1678-86212017000200152

Peña, A., Calavera, J., \& Llorens, M. (2011). Recommendations for the basement wall analysis, subjected to vertical loads originated by the façade pillars. Revista de la Construcción, 10, 122-141. doi.org/10.4067/S0718-915X2011000200011

Sumathi, A., \& Mohan, K.S.R. (2014). Study on the effect of compressive strength of brick masonry with admixed mortar. International Journal of ChemTech Research, 6(7), 3437-3450.

Thamboo, J.A., \& Dhanasekar, M. (2019). Correlation between the performance of solid masonry prisms and wallettes under compression. Journal of Building Engineering, 23, 429-438. doi.org/10.1016/j.jobe.2019.01.007

Vercher, J., Cubel, F, Gil, E., \& Lerma, C. (2018). Design and construction recommendations for connections arrangement in anchored veneers with continuous air cavity. Revista de la Construcción, 17(1), 137-148. doi.org/10.7764/RDLC.17.1.137 